\title{
TRANSORAL DECOMPRESSION AND POSTERIOR FUSION FOR RHEUMATOID ATLANTO-AXIAL SUBLUXATION
}

\author{
H. A. CROCKaRd, J. L. POZO, A. O. Ransford, J. M. STEVens, B. E. Kendall, W. K. ESSigman
}

\author{
From University College Hospital and the National Hospital for Nervous Diseases, London
}

\begin{abstract}
Cervical myelopathy is an uncommon but potentially fatal complication of rheumatoid atlanto-axial subluxation. Computerised myelotomography with three-dimensional reconstruction shows that rheumatoid pannus, together with the odontoid peg, contributes significantly to anterior cervico-medullary compression. These findings were the basis for treatment by transoral anterior decompression and posterior occipitocervical fusion, which removes both bony and soft-tissue causes of compression and allows early mobilisation without major external fixation.
\end{abstract}

We report encouraging results from this combined approach in 14 patients who had progressive neurological deterioration.

The high incidence of atlanto-axial subluxation in rheumatoid arthritis, and its potential for acute spinal cord compression and sudden death, have been widely documented (Conlon, Isdale and Rose 1966; Smith, Benn and Sharp 1972; Mathews 1974). Cervical myelopathy, though a less common complication, has become increasingly recognised over the last decade (Nakano 1975; Cabot and Becker 1978; Marks and Sharp 1981). In patients treated conservatively, reported figures suggest that there is a $50 \%$ mortality within one year of the onset of symptoms; this emphasises the serious import of neurological complications (Marks and Sharp 1981; Meijers et al. 1984).

Neural involvement is accepted as the main indication for operative intervention in rheumatoid atlantoaxial subluxation (Newman and Sweetnam 1969; Ferlic et al. 1975; Ranawat et al. 1979; Conaty and Mongan 1981: Meijers et al. 1984). However, the results of operation, usually a posterior cervical fusion with or without decompression, have been unsatisfactory: "a high, early mortality rate is common and unavoidable" (Hamblen 1983).

CT scanning has recently helped to define the bony

H. A. Crockard, FRCS, Consultant Neurosurgeon

J. M. Stevens. MRACR. FRCR. Consultant Radiologist

B. E. Kendall. FRCP. FRCR. Consultant Radiologist

The National Hospital for Nervous Diseases, Queen Square, London

WCIN 3BG. England

J. L. Pozo. FRCS, Orthopaedic Senior Registrar

Whittington Hospital. Highgate Hill, London N19 5NF, England.

A. O. Ransford. FRCS. Consultant Orthopaedic Surgeon

University College Hospital. Gower Street, London WCIE 6AU, England

W. K. Essigman. FRCP. Consultant Rheumatologist

The Lister Hospital, Coreys Mill Lane. Stevenage. Hertfordshire SGI $4 \mathrm{AB}$. England.

Requests for reprints should be sent to $\mathrm{Mr} \mathrm{H}$. A. Crockard.

c 1986 British Editorial Society of Bone and Joint Surgery $0301620 \times 863082 \$ 2.00$ abnormalities at the craniocervical junction in rheumatoid arthritis (Redlund-Johnell 1984). In the present study computerised myelotomography with multiplanar reconstruction and new water-soluble contrast materials have been used to localise and identify the causes of compression in atlanto-axial subluxation. This technique clearly demonstrates the important contribution of proliferative rheumatoid pannus behind the odontoid peg to anterior cervico-medullary compression. In the light of these findings, transoral excision of both the odontoid peg and the soft-tissue pannus has been undertaken, in conjunction with a conventional posterior occipitocervical fusion. This one-stage combined operation achieves neurological decompression and, at the same time, allows early mobilisation of the patient without the need for major external fixation.

We present the findings and the early results of the operation in 14 patients with progressive neurological deterioration secondary to rheumatoid atlanto-axial subluxation.

\section{CLINICAL MATERIAL}

Nineteen patients with clinical evidence of progressive myelopathy secondary to atlanto-axial subluxation were investigated radiologically. Of these, two refused operation and three were managed conservatively because of severe medical problems. The remaining 14 patients had combined transoral decompression and posterior occipitocervical stabilisation. These form the basis of this report, and their clinical details are summarised in Table I.

There were 11 female and three male patients, with ages ranging from 19 to 78 years at the time of operation, and averaging 57.8 years. The duration of rheumatoid disease before the onset of neurological complications averaged 18 years, with a range of 6 to 40 years. The interval from the onset of symptoms to operation ranged 
from 1 to 30 months, averaging 9.8 months. Ten of the patients had classic seropositive rheumatoid arthritis, the other four were seronegative. All but two patients had been given steroids as part of their medical treatment. Twelve of the patients had undergone multiple orthopaedic operations, mainly replacement arthroplasties. Postoperative follow-up was from six months to four years.

All the patients had cervical pain or occipital neuralgia or both. This had often preceded the onset of neurological symptoms and was aggravated by neck movement. Thirteen patients had marked sensory disturbance, mainly numbness or intense paraesthesia with a highly variable dermatome distribution. Lhermitte's sign, electric-like shocks through the trunk and limbs on maximum cervical flexion, was present in six of the 14 patients. Two patients (Cases 3 and 5) had tetraparesis with sphincter dysfunction and were wheelchair-bound on presentation. Hyper-reflexia and extensor plantar responses could be elicited in all cases. Loss of the gag reflex and respiratory difficulties were seen in two patients found to have vertical translocation of the odontoid peg.

Neural involvement was defined according to the

Table I. Clinical details of 14 patients who had the combined operation for anterior atlanto-axial subluxation

\begin{tabular}{|c|c|c|c|c|c|c|c|c|c|c|c|c|}
\hline Case & $\begin{array}{l}\text { Age } \\
\text { (yrs) }\end{array}$ & Sex & $\begin{array}{l}\text { Duration of } \\
\text { rheumatoid } \\
\text { disease } \\
\text { (yrs) }\end{array}$ & $\begin{array}{l}\text { Duration of } \\
\text { cervical } \\
\text { myelopathy } \\
\text { (months) }\end{array}$ & $\begin{array}{l}\text { Sensory } \\
\text { disturbance }\end{array}$ & $\begin{array}{l}\text { Motor } \\
\text { weakness }\end{array}$ & $\begin{array}{l}\text { Radiogra } \\
\text { (slip in m }\end{array}$ & $\begin{array}{l}\text { aphy } \\
\text { nm) }\end{array}$ & $\begin{array}{l}\text { Computerised } \\
\text { myelo- } \\
\text { tomography }\end{array}$ & Operation & Outcome* & $\begin{array}{l}\text { Follow-up } \\
\text { (months) }\end{array}$ \\
\hline 1 & 78 & M & 6 & 1 & $\begin{array}{l}\text { Sensory loss } \\
\text { L arm }\end{array}$ & Arms and legs & AAS & 10 & $\begin{array}{l}\text { Pannus }+++ \\
\text { Dens erosion }\end{array}$ & $\mathrm{TAD}+\mathrm{OCF}$ & $\underset{\text { III } \rightarrow \text { II }}{\text { Improved }}$ & $\begin{array}{l}25 \\
\text { Died } \\
\text { myocardial } \\
\text { infarction }\end{array}$ \\
\hline 2 & 54 & M & 27 & 6 & $\begin{array}{l}\text { Sensory loss } \\
\text { both arms } \\
\text { Lhermitte+ }\end{array}$ & Both arms & $\begin{array}{l}\text { AAS } \\
\text { C4 } 5 \text { slip }\end{array}$ & $p^{7}$ & $\begin{array}{l}\text { Pannus }+ \\
\text { Dens erosion }\end{array}$ & $\begin{array}{l}\text { TAD + OCF } \\
\text { Cloward } \\
\text { C4 } 5\end{array}$ & $\begin{array}{l}\text { Improved } \\
\text { III } \rightarrow \text { II }\end{array}$ & 22 \\
\hline 3 & 67 & $\mathrm{~F}$ & 8 & 8 & $\begin{array}{l}\text { Sensory loss } \\
\text { arms and legs }\end{array}$ & $\begin{array}{l}\text { Tetraparesis } \\
\text { Sphincter loss }\end{array}$ & $\begin{array}{l}\text { AAS } \\
\text { C2-3 slip }\end{array}$ & $p^{9}$ & Pannus + & $\begin{array}{l}\text { TAD + OCF } \\
\text { Split palate }\end{array}$ & $\begin{array}{l}\text { Walking } \\
\text { III } \rightarrow \text { I }\end{array}$ & 45 \\
\hline 4 & 56 & $\mathrm{~F}$ & 13 & 12 & $\begin{array}{l}\text { Paraesthesia } \\
\text { both arms }\end{array}$ & Arms and legs & AAS & 5 & $\begin{array}{l}\text { Pannus }++ \\
\text { Translocation }\end{array}$ & $\begin{array}{l}\text { TAD + OCF } \\
\text { Split palate }\end{array}$ & $\begin{array}{l}\text { Improved } \\
\text { III } \rightarrow \text { I }\end{array}$ & 24 \\
\hline 5 & 67 & $\mathrm{~F}$ & 11 & 30 & $\begin{array}{l}\text { Sensory loss } \\
\text { arms and legs }\end{array}$ & $\begin{array}{l}\text { Tetraparesis } \\
\text { Sphincter loss }\end{array}$ & $\begin{array}{l}\text { AAS } \\
\text { C2-5 slip }\end{array}$ & ${ }^{9}$ & Pannus ++ & $\begin{array}{l}\text { TAD + OCF } \\
\text { Split palate }\end{array}$ & $\begin{array}{l}\text { Walking } \\
\text { III } \rightarrow \text { I }\end{array}$ & $\begin{array}{l}15 \\
\text { Died Ca } \\
\text { breast }\end{array}$ \\
\hline 6 & 53 & $\mathrm{~F}$ & 27 & 5 & $\begin{array}{l}\text { Paraesthesia } \\
\text { R arm }\end{array}$ & Both hands & $\begin{array}{l}\text { AAS } \\
\text { C2-Tl sl }\end{array}$ & $\begin{array}{c}6 \\
\text { slips }\end{array}$ & Pannus ++ & $\begin{array}{l}\text { TAD + OCF } \\
\text { Cloward } \\
\text { C4-5 }\end{array}$ & $\underset{I I I \rightarrow I}{\text { Improved }}$ & 12 \\
\hline 7 & 45 & $\mathrm{~F}$ & 40 & 2 & $\begin{array}{l}\text { Sensory loss } \\
\text { both hands }\end{array}$ & Both arms & AAS & 10 & $\begin{array}{l}\text { Dens replaced } \\
\text { by pannus } \\
+++\end{array}$ & $\begin{array}{l}\text { TAD + OCF } \\
\text { Split } \\
\text { mandible }\end{array}$ & $\underset{I I I I \rightarrow I}{\text { Improved }}$ & 20 \\
\hline 8 & 69 & $\mathrm{~F}$ & 8 & 6 & $\begin{array}{l}\text { Sensory loss } \\
\text { both hands } \\
\text { Lhermitte + }\end{array}$ & - & $\begin{array}{l}\text { AAS } \\
\text { C4 } 5 \text { slip }\end{array}$ & $p^{10}$ & $\begin{array}{l}\text { Pannus }++ \\
\text { Fracture of } \\
\text { odontoid }\end{array}$ & TAD + OCF & $\underset{\text { IIII } \rightarrow \text { I }}{\text { Improved }}$ & 11 \\
\hline 9 & 34 & $\mathbf{M}$ & 18 & 24 & $\begin{array}{l}\text { Sensory loss } \\
\text { arms and legs } \\
\text { Lhermitte }+\end{array}$ & $\begin{array}{l}\text { Spastic limbs } \\
\text { Respiratory } \\
\text { irregularity }\end{array}$ & AAS & 14 & $\begin{array}{l}\text { Pannus + } \\
\text { Trans- } \\
\text { location }\end{array}$ & $T A D+O C F$ & $\underset{\text { III } \rightarrow \text { I }}{\text { Improved }}$ & 11 \\
\hline 10 & 19 & $\mathrm{~F}$ & 16 & 14 & $\begin{array}{l}\text { Numb L leg } \\
\text { Lhermitte }+\end{array}$ & Both arms & AAS & 5 & $\begin{array}{l}\text { Pannus }+++ \\
\text { Dens erosion }\end{array}$ & $\mathrm{TAD}+\mathrm{OCF}$ & $\begin{array}{l}\text { Improved } \\
\text { III } \rightarrow \text { I }\end{array}$ & 10 \\
\hline 11 & 63 & $\mathrm{~F}$ & 12 & 1 & $\begin{array}{l}\text { Paraesthesia } \\
\text { both hands }\end{array}$ & Arms and legs & AAS & 10 & Pannus ++ & $\begin{array}{l}\text { TAD + OCF } \\
\text { Split palate }\end{array}$ & $\underset{I I I \rightarrow I}{\text { Improved }}$ & 15 \\
\hline 12 & 69 & $\mathrm{~F}$ & 18 & 7 & $\begin{array}{l}\text { Sensory loss } \\
\text { both arms } \\
\text { Lhermitte + }\end{array}$ & - & AAS & 5 & Pannus + & $\begin{array}{l}\text { TAD + OCF } \\
\text { Split palate }\end{array}$ & $\underset{I I \rightarrow I}{\text { Improved }}$ & 18 \\
\hline 13 & 64 & $F$ & 30 & 12 & Lhermitte + & Arms and legs & AAS & 6 & Pannus + & $T A D+O C F$ & $\underset{\text { III } \rightarrow \text { Improved }}{ }$ & 16 \\
\hline 14 & 72 & $\mathrm{~F}$ & 29 & 30 & $\begin{array}{l}\text { Paraesthesia } \\
\text { arms and legs }\end{array}$ & $R$ arm and leg & AAS & 6 & $\begin{array}{l}\text { Pannus }+ \\
\text { Malrotation } \\
\text { of atlas on } \\
\text { axis }\end{array}$ & $\begin{array}{l}\text { Failed TAD } \\
\text { Haemorrhage }\end{array}$ & $\begin{array}{l}\text { Deterior- } \\
\text { ation } \\
\text { III }\end{array}$ & 6 \\
\hline
\end{tabular}

* Conaty \& Mongan (1981) classification, see text

AAS. atlanto-axial subluxation

TAD. transoral anterior decompression

OCF. occipito-cervical fusion 


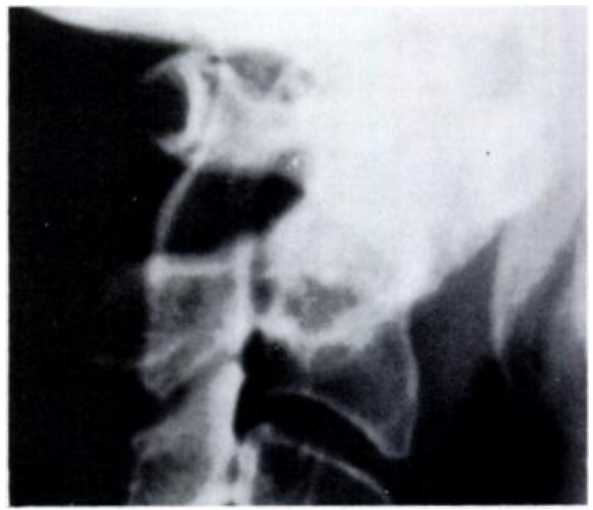

Fig. I

Cervical myelogram in a patient with atlantoaxial subluxation, showing erosion of the posterior margin of the dens and, at the same level. an anterior indentation in the column of contrast. The odontoid peg is not in direct contact with the anterior dura.

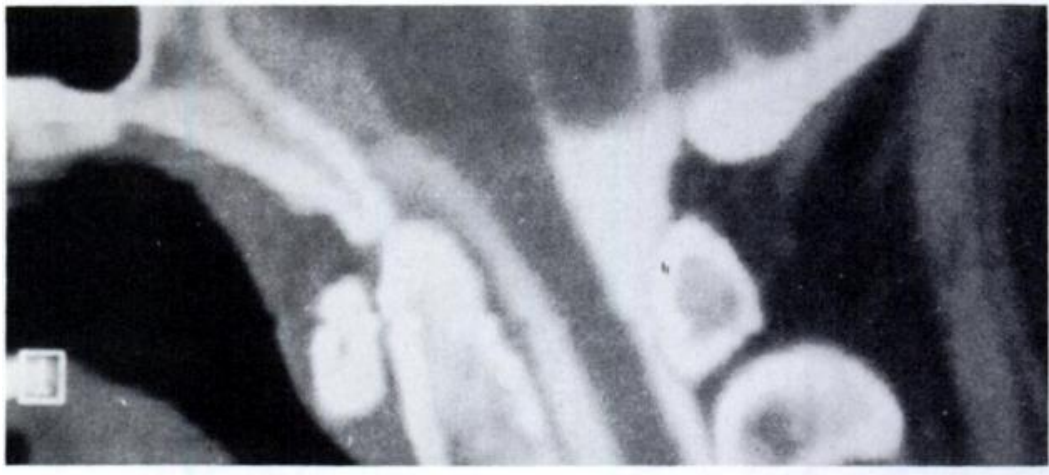

Fig. 2

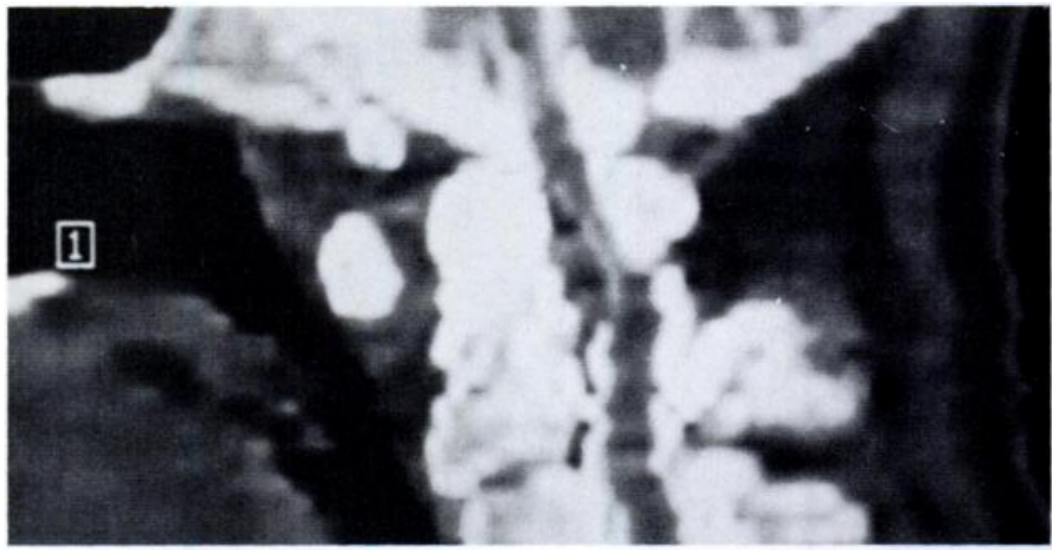

Fig. 4

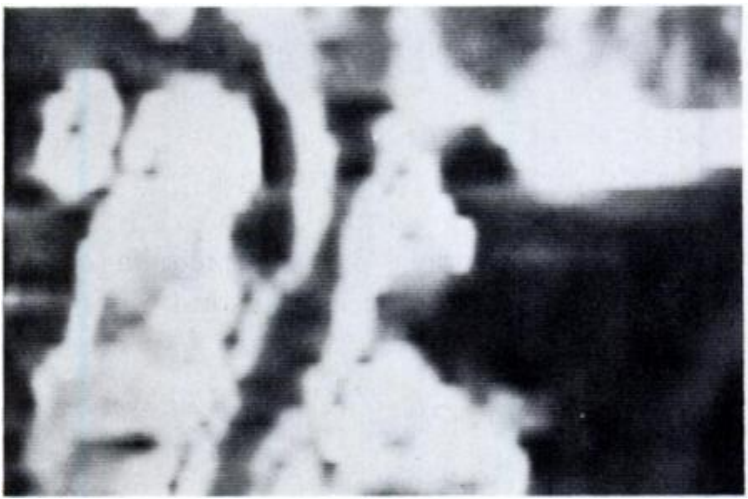

4Fig. 6

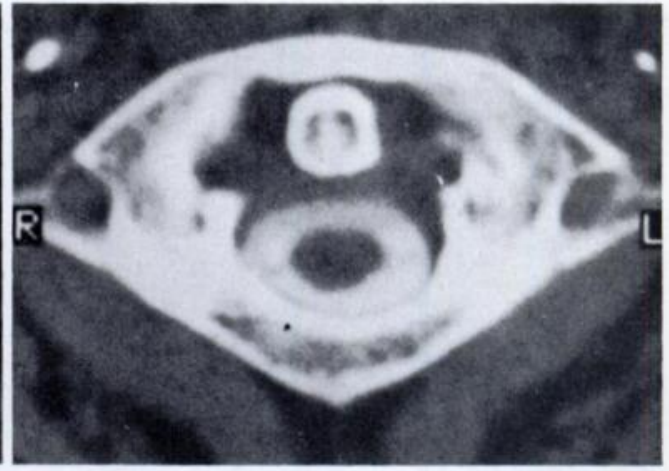

Fig. 3

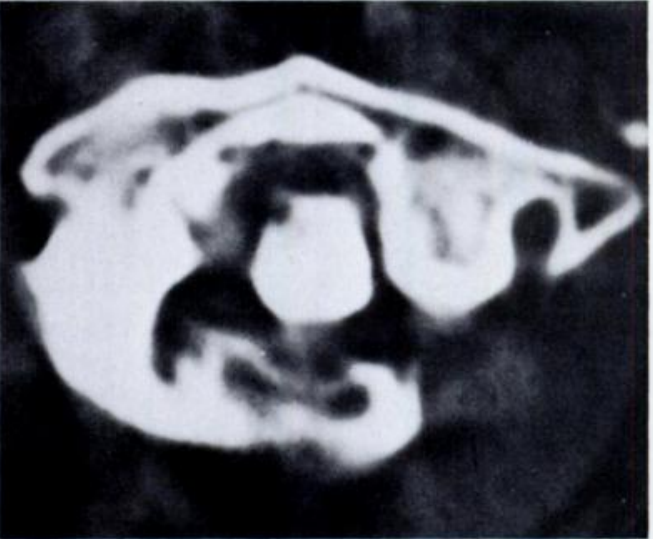

Fig. 5

Computerised myelotomograms. Figures 2 and 3-Sagittal and horizontal reconstructions of a normal atlanto-axial complex. showing the odontoid peg in close apposition to the anterior arch of the atlas. The spinal cord, surrounded by a uniform ring of contrast medium, lies well back in the canal. Figures 4 and 5-Sagittal and horizontal reconstructions from a case of rheumatoid atlanto-axial subluxation. The anterior arch of the atlas has subluxated forwards from the dens. The odontoid peg and the mass of pannus behind it are compressing the spinal cord into a dumb-bell shape. Figure 6Sagittal reconstruction in the same patient, after reduction of the subluxation, showing that there is still compression of the spinal cord. 
classification of Conaty and Mongan (1981):

Stage I. Complaints of paraesthesia but no objective neurological deficit.

Stage II. Complaints of weakness and paraesthesia but only hyperflexia on objective examination.

Stage III. Subjective complaints including loss of function. with objective evidence of weakness and long tract signs.

Of the 14 patients 12 were in Stage III and two in Stage II.

\section{METHODS}

\section{Investigations}

Plain radiography. All 14 patients had lateral cervical films in maximum flexion and extension to define the degree of atlanto-axial subluxation. Maximum displacement ranged from 5 to $14 \mathrm{~mm}$, with an average of $8 \mathrm{~mm}$. Vertical translocation of the odontoid peg with encroachment into the foramen magnum was observed in two patients (Cases 4 and 9). Five of the 14 patients showed evidence of concomitant disease at levels below the axis (Table I). Extensive staircase subluxation from C2 to T1 was noted in Case 6.
GE 8800 CT scanning system. Four millilitres of Niopam, a non-ionic water-soluble contrast medium. was injected via the lumbar route and sequential highresolution axial sections $1.5 \mathrm{~mm}$ in thickness recorded over the affected area.

Sagittal and horizontal reconstructions through the normal atlanto-axial complex show the odontoid peg in close apposition to the anterior arch of the atlas, and the spinal cord surrounded by a uniform ring of contrast, lying well back in the canal (Figs 2 and 3 ).

The typical appearance in rheumatoid atlanto-axial subluxation was that the arch of the atlas was subluxated forwards from the dens, and although this displacement was often not marked, the spinal cord was found to be compressed by a soft-tissue mass from its normal ringlike shape into a dumb-bell configuration (Figs 4 and 5). This mass, between the odontoid peg and the anterior dura, was histologically confirmed as proliferative rheumatoid pannus, and was present in all 14 patients.

Flexion and extension studies were carried out in six patients. These confirmed that in the position of maximum displacement, both the odontoid and the mass of pannus contributed to cord compression. Reduction of

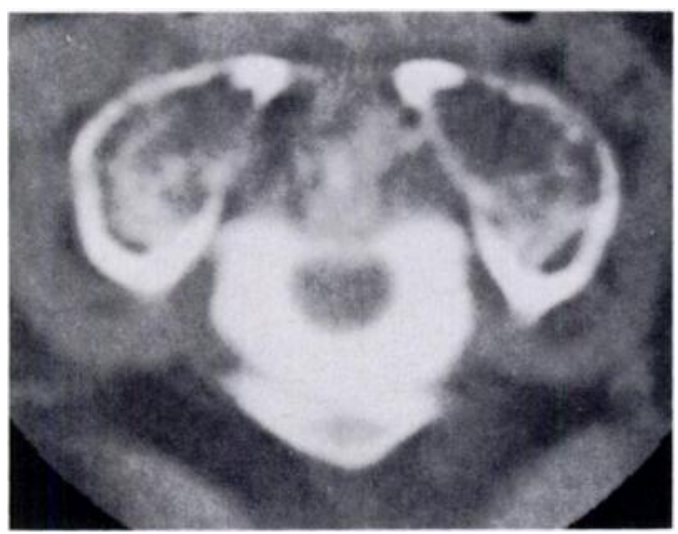

Fig. 7

Computerised myelotomogram. Horizontal reconstruction at the level of the apex of the odontoid peg showing compression of the cervico-medullary junction.

Cervical myelography. Previous experience had shown the difficulties of this investigation in disabled rheumatoid patients. It is often unsuccessful because of poor patient tolerance and may not provide useful unequivocal information. In this series, the first four patients had cervical myelography before computerised myelotomography. When the investigation was satisfactory a frequent finding was erosion of the posterior aspect of the odontoid peg at the level of the transverse ligament, with a corresponding anterior indentation in the contrast column which was clearly separated from the odontoid peg (Fig. 1).

Computerised myelotomography. All 14 patients had computerised myelotomography with multiplanar reconstruction of the craniocervical junction, using a the subluxation in some patients failed to relieve completely the compression of the spinal cord, and a sufficiently bulky pannus mass could be responsible on its own account for compression of the anterior neural structures (Fig. 6). In the two patients with translocation of the odontoid peg into the foramen magnum, the rheumatoid pannus extended to the apex of the dens, thereby contributing to compression of the medulla (Fig. 7).

Operation. The technique of transoral anterior decompression has been described in detail elsewhere (Crockard 1985), but its salient features are summarised here with reference to our 14 patients.

Skull traction is not employed at any stage in the operative management. In the first 10 cases, a tracheostomy and splitting the soft palate were performed to help 


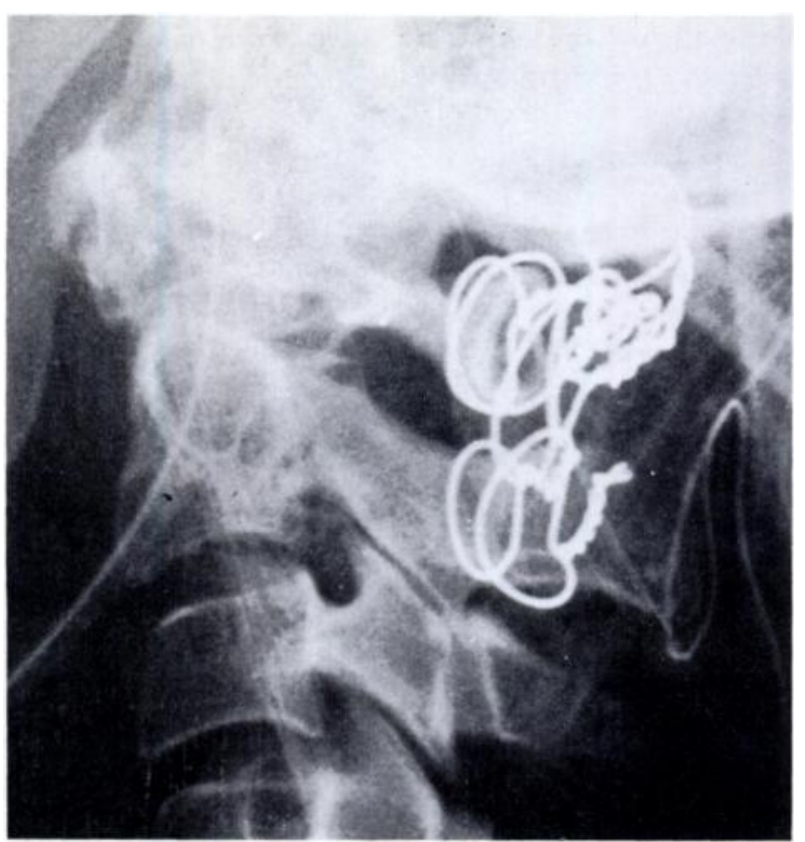

Fig. 8

Radiograph showing posterior occipitocervical fixation with sublaminar and transoccipital wires.

transoral access. Increasing experience has allowed modifications in the last four cases, the tracheostomy being avoided by the use of an armoured nasotracheal tube (Mallinkrodt, National Catheter Corporation, USA), and division of the soft palate by its retraction into the nasopharyngeal space with a nasal catheter.

The posterior pharyngeal wall is incised in the midline and accurate localisation of $\mathrm{C} 1-\mathrm{C} 2$ achieved radiographically. Using an operating microscope, $1 \mathrm{~cm}$ of the anterior arch of the atlas is removed. The odontoid peg is burred away until the pre-spinal space is entered. The pannus mass is then excised, thereby decompressing the dura. The pharynx is closed in layers without tension.

The patient is then turned into the prone position and an occipito-atlanto-axial fusion by wiring and bone graft is performed (Fig. 8). Ventilation of the patient is continued overnight after the operation. As soon as comfort allows, the patient is helped to sit up, with some posterior support. The cuffed tube is removed on the fifth day, nasogastric feeding is discontinued, and the patient allowed up in a firm pre-formed cervical collar.

\section{RESULTS}

Thirteen of the 14 patients had marked subjective and objective improvement in their neurological status after operation. This occurred within four weeks and has so far been maintained. The two tetraparetic patients recovered sufficiently to walk out of hospital on crutches. Cervical or occipital pain resolved in all cases. Using the classification of Conaty and Mongan (1981), 11 patients improved to Stage I, two to Stage II and one continued to deteriorate (Case 14).
Case 14 has been included in this report for illustrative purposes. During the transoral approach, severe haemorrhage occurred when the burr perforated the vertebral artery in the midline. The bleeding was eventually. stopped but the decompression and stabilisation had to be abandoned. Retrospective analysis showed that the atlas had rotated through about 90 in a plane horizontal to the axis, bringing the artery directly into the midline. This patient has continued to deteriorate neurologically despite conservative treatment.

Two patients experienced minor complications: one required resuture of dehiscence of the soft palate and a second developed nasal regurgitation due to late fibrotic contracture of the soft palate. None of the posterior pharyngeal wounds became infected.

There have been no peroperative deaths. Two patients (Cases 1 and 5) have died 15 and 24 months postoperatively, from carcinomatosis and from myocardial infarction respectively.

\section{DISCUSSION}

Operation for rheumatoid atlanto-axial subluxation is undertaken primarily for neurological complications (Ranawat et al. 1979; Conaty and Mongan 1981; Meijers et al. 1984). The standard operative techniques aim at reduction, or at best, stabilisation of the atlanto-axial complex. Rana et al. (1973) and Ranawat et al. (1979) favour a $\mathrm{Cl}-\mathrm{C} 2$ fusion, but incorporate the occiput when subluxation is irreducible. Jeffreys (1980) and Meijers $e t$ al. (1984) routinely include the occiput in their fixation on the basis that the atlanto-occipital joints are unlikely to be normal. Laminectomy, in conjunction with enlargement of the foramen magnum, has been advocated when the atlas is tilted forwards on the axis (Meijers et al. 1984). Whatever the technique, the overall results of posterior cervical surgery have been unsatisfactory (Hamblen 1983). The results from published series, summarised in Table II, show a significant operative mortality, and a $33 \%$ mortality at two years for patients undergoing surgery for cervical myelopathy. Adding patients who did not improve or who deteriorated as a result of operation gives a combined morbidity and mortality of $50 \%$ for all cases.

Although rheumatoid pannus has been noted at atlanto-axial level in postmortem studies (Boyle 1971), its role in the causation of cervical myelopathy has been largely unsuspected and unsubstantiated. Computerised myelotomography not only demonstrates the presence of pannus behind the odontoid peg. but also allows an accurate evaluation of its role in cervico-medullary compression. Flexion-extension studies show that in the subluxated position, both the abnormally located odontoid and the pannus contribute to cord compression. When the displacement is reduced, the granulomatous mass may continue to distort the neural structures. Where there is an element of vertical translocation, extension of the soft-tissue mass to the apex of the dens will intensify 
Table II. Previous reports of the result of posterior cervical operations for patients with myelopathy secondary to atlanto-axial subluxation

\begin{tabular}{|c|c|c|c|c|c|}
\hline Authors & $\begin{array}{l}\text { Number of } \\
\text { patients }\end{array}$ & Operative fixation & $\begin{array}{l}\text { Patients with } \\
\text { no improvement } \\
\text { (per cent) }\end{array}$ & $\begin{array}{l}\text { Peroperative } \\
\text { deaths } \\
\text { (per cent) }\end{array}$ & $\begin{array}{l}\text { Two-year } \\
\text { mortality } \\
\text { (per cent) }\end{array}$ \\
\hline Cregan 1966 & 7 & $\begin{array}{l}\text { Occipito-cervical } \\
\text { Atlanto-axial }\end{array}$ & 43 & 15 & 15 \\
\hline Hamblen 1983 & 14 & $\begin{array}{l}\text { Occipito-cervical } \\
\text { Atlanto-axial }\end{array}$ & 15 & - & 20 \\
\hline Crellin. Maccabe and Hamilton 1970 & 6 & Atlanto-axial & 0 & 33 & 33 \\
\hline Boyle 1971 & 4 & Occipito-cervical & 25 & 50 & 75 \\
\hline Ferlic et al. 1975 & 12 & Atlanto-axial & 33 & 25 & 33 \\
\hline Ranawat et al. 1979 & 19 & $\begin{array}{l}\text { Occipito-cervical } \\
\text { Atlanto-axial }\end{array}$ & 32 & 26 & 37 \\
\hline Conaty and Mongan 1981 & 21 & $\begin{array}{l}\text { Occipito-cervical } \\
\text { Atlanto-axial } \\
\pm \text { Decompression }\end{array}$ & 38 & 5 & 10 \\
\hline Meijers et al. 1984 & 29 & $\begin{array}{l}\text { Occipito-cervical } \\
\text { Atlanto-axial } \\
\pm \text { Decompression }\end{array}$ & 21 & 12 & 32 \\
\hline
\end{tabular}

compression of the medulla. The knowledge that there may be a mass of pannus between dens and dura helps explain the frequent observation that the severity of the neurological deficit does not correlate with the degree of atlanto-axial subluxation revealed by a lateral radiograph (Cregan 1966; Rana et al. 1973; Cabot and Becker 1978; Marks and Sharp 1981).

The accurate localisation and definition of the causes of compression at the craniocervical junction allow a more direct approach to operation. The contribution of both rheumatoid pannus and the odontoid peg to compression of the cord would argue the logic of direct anterior decompression, removing both the bony and soft-tissue components, and relieving any medullary compression from a vertically translocated odontoid. Sukoff, Kadin and Moran (1972) performed a transoral decompression in a tetraparetic patient six months after an occipitocervical fusion had failed to relieve symptoms. Neurological recovery was marred by the considerable morbidity which resulted from prolonged immobilisation. This consideration and the difficulties of providing nursing care for these disabled patients, when they have long periods on skull traction, encouraged the authors to combine transoral decompression with posterior stabilisation, so as to allow earlier mobilisation of the patient.

Transoral decompression provides some immediate advantages. Since the structures causing compression at the anterior cervico-medullary junction are excised, preoperative traction to reduce the subluxation and intraoperative methods of securing the reduction are no longer necessary. Conventional operation requires prolonged postoperative immobilisation to maintain the improved $\mathrm{Cl}-\mathrm{C} 2$ configuration, often with very limited success (Conaty and Mongan 1981). Ferlic et al. (1975) found that these arthritic patients were unable to tolerate halo-braces, casts or plaster jackets. Three months' skull traction on a Stryker bed demands "great patience and endurance from the patients and from all those who cared for them" (Meijers et al. 1974).

The excision of the odontoid peg and the pannus eliminates the possibility of acute spinal compression from these elements. The authors therefore considered that occipitocervical fixation in combination with a firm pre-moulded collar would adequately control mobility at atlanto-axial level. Stabilisation in situ, routinely incorporating the occiput, compensates for the loss of the apical and alar ligaments. The surgical division of all ligaments between occiput and axis, if not already destroyed by disease, would allow some forward migration of the atlas on the axis (Werne 1957). However, the membrana tectoria, though it is perforated centrally during the approach to the pre-spinal space, retains its lateral continuity and provides a major check to movement in the anteroposterior plane. This has been confirmed by radiographic studies at follow-up, which show only a minimal increase in movement at this level after stabilisation by the sublaminar wiring of $\mathrm{Cl}$ and $\mathrm{C} 2$ to the occiput. In the long term, bony fusion is achieved by using cancellous bone chips from the iliac crest (Newman and Sweetnam 1969).

The results of the combined procedure are encouraging though the follow-up is short. The 13 patients who had an adequate decompression and stabilisation have shown continued neurological improvement. Development of the operative technique, avoiding both tracheostomy and soft-palate split, will further reduce softtissue complications. Postoperatively, meticulous oral hygiene and the use of nasogastric feeding have helped to avoid infection of the pharyngeal wounds. There have been no peri-operative deaths. This may reflect not only the success of the anterior decompression, but also that 
of the regime of early mobilisation, which must reduce morbidity and mortality in this susceptible group. However, it must be emphasised that this operative procedure can be recommended, at present, only for patients with established cervical myelopathy in whom pannus has been shown to contribute to cervico-medullary compression.

The diagnosis of cervical myelopathy in patients with long-standing rheumatoid arthritis requires a high index of suspicion and painstaking monitoring of symptoms and signs. Multiple joint involvement and peripheral neuropathies often make clinical assessment very difficult; only detailed examination, including position sense, sensory appreciation and plantar responses, will reveal unsuspected myelopathy (Crellin, Maccabe and Hamilton 1970). Nevertheless, the poor prognosis associated with progressive neurological deterioration makes early diagnosis and effective surgical treatment even more important (Marks and Sharp 1981).

Conclusions. Computerised myelotomography allows an accurate analysis of the compressive factors acting at the craniocervical junction in rheumatoid atlanto-axial subluxation.

Rheumatoid pannus plays an important role in the pathogenesis of cervical myelopathy at this level.

Transoral anterior decompression and posterior cervical stabilistion removes both the bony and softtissue elements of compression and allows early mobilisation of the patient, thereby reducing morbidity and mortality.

The authors wish to thank Mr D. Ellis for his consistent and excellent photography.

\section{REFERENCES}

Boyle AC. The rheumatoid neck (Ernest Fletcher memorial lecture) Proc R Soc Med 1971:64:11615.

Cabot A. Becker A. The cervical spine in rheumatoid arthritis. Clin Orthop 1978:131: 13040.
Conaty JP, Mongan ES. Cervical fusion in rheumatoid arthritis. $J$ Bone Joint Surg $[$ Am $] 1981 ; 63-$ A: 1218-27.

Conlon PW, Isdale IC, Rose BS. Rheumatoid arthritis of the cervical spine: an analysis of 333 cases. Ann Rheum Dis 1966:25:120-6.

Cregan JC. Internal fixation of the unstable rheumatoid cervical spine. Ann Rheum Dis 1966;25:242-52.

Crellin RQ, Maccabe JJ, Hamilton EBD. Severe subluxation of the cervical spine in rheumatoid arthritis. J Bone Joint Surg $[\mathrm{Br}]$ 1970; 52-B: 244-51.

Crockard HA. The transoral approach to the base of the brain and upper cervical cord. Ann R Coll Surg Engl 1985:67:321 5.

Ferlic DC, Clayton ML, Leidholt JD, Gamble WE. Surgical treatment of the symptomatic unstable cervical spine in rheumatoid arthritis. J Bone Joint Surg [Am] 1975;57-A:349 54.

Hamblen DL. Occipito-cervical fusion: indications, technique and results. J Bone Joint Surg [Br] 1967;49 B:33 45.

Hamblen DL. Surgical management of rheumatoid arthritis: the cervical spine. In: Harris NH, ed. Postgraduate texthook of clinical orthopaedics. Bristol etc: Wright PGS, 1983:487 97.

Jeffreys E. Disorders of the cervical spine. London etc: Butterworths, 1980: $106-18$.

Marks JS, Sharp J. Rheumatoid cervical myelopathy: $Q J$ Med 1981; 199:307 19.

Mathews JA. Atlanto-axial subluxation in rheumatoid arthritis: a 5-year follow-up study. Ann Rheum Dis 1974:33:526-31.

Meijers KAE, Van Beusekom GTh, Luyendijk W, Duijfjes F. Dislocation of the cervical spine with cord compression in rheumatoid arthritis. J Bone Joint Surg [Br] 1974:56 B:668 80.

Meijers KAE, Cats A, Kremer HPH, Luyendijk W, Onvlee GJ, Thomeer RT. Cervical myelopathy in rheumatoid arthritis. Clin Exp Rheumatol 1984:2:239-45.

Nakano KK. Neurologic complications of rheumatoid arthritis. Orthop Clin North Am 1975:6:861-80.

Newman P, Sweetnam R. Occipito-cervical fusion: an operative technique and its indications. $J$ Bone Joint Surg $[\mathrm{Br}]$ 1969;51-B: 423-31.

Rana NA, Hancock DO, Taylor AR, Hill AGS. Atlanto-axial subluxation in rheumatoid arthritis. J Bone Joint Surg $[B r]$ 1973; 55- B : $458-70$.

Ranawat CS, O'Leary P, Pellicci P, Tsairis P, Marchisello P, Dorr L. Cervical spine fusion in rheumatoid arthritis. J Bone Joint Surg [Am] 1979:61-A: 1003-10.

Redlund-Johnell I. Dislocations of the cervical spine in rheumatoid arthritis. Thesis. Malmö, 1984:69--89.

Smith PH, Benn RT, Sharp J. Natural history of rheumatoid cervical luxations. Ann Rheum Dis 1972;31:431 9.

Sukoff MH, Kadin MM, Moran T. Transoral decompression for myelopathy caused by rheumatoid arthritis of the cervical spine: case report. J Neurosurg 1972:37:493 7.

Werne S. Studies in spontaneous atlas dislocation. Acta Orthop Scand 1957:Suppl 23:11-141 